\title{
IMPACT OF FISCAL DECENTRALISATION ON ECONOMIC DEVELOPMENT IN THE EUROPEAN UNION
}

\author{
[Vliv fiskální decentralizace na ekonomický rozvoj v Evropské unii] \\ Irena Szarowská ${ }^{1}$ \\ ${ }^{1}$ Slezská univerzita, Obchodně podnikatelská fakulta, Univerzitní nám. 1934/3,733 40 Karviná \\ Email:szarowska@opf.slu.cz.
}

\begin{abstract}
The article investigates the impact of fiscal decentralisation on a long-term economic development. The aim of the article is to examine and quantify influence of fiscal decentralisation on output in the European Union in the period 1995-2012. The empirical evidence (based on data taken from OECD Fiscal Decentralisation Database and OECD) is performed on a panel which contains 21 countries. Methodology is applied in accordance to Blöchliger (2013), but explanatory variables are not examined in individual regressions, but the analysis newly uses Generalized Method of Moments (Dynamic Panel Data). For a model specification, Dynamic Panel Data Model Wizard is applied. Results of dynamic panel analysis suggest positive impact of expenditure decentralisation, negative effect of revenue decentralisation and negative but statistically insignificant impact of tax decentralisation on economic development. Based on the empirical results, the study suggests that sub-central governments should be given more autonomy and authority in fiscal expenditure matters. These findings are interesting as central governments must often face to tendence of sub-central governments to increase revenue fiscal decentralisation over the last years.
\end{abstract}

Keywords: dynamic panel data, economic development, expenditure decentralisation, fiscal decentralisation, fiscal federalism, revenue decentralisation.

JEL classification: E62, H71, H72, H77

Doručeno redakci: 9.2.2015; Recenzováno: 2.3.2015; 10.3.2015; Schváleno k publikování: 23.9.2015

\section{Introduction}

Scope of fiscal decentralisation and intergovernmental fiscal frameworks usually reflect fundamental societal choices and history and are not foremost geared towards achieving economic policy objectives. Fiscal relations affect the behaviour of firms, households and governments and thereby economic activity. Firms' investment decisions are affected by the productivity of the public sector, and differences between costs and benefits of service provision across jurisdictions may induce them to change their location. Similarly, labour supply decisions by households will be affected by differences in taxation across jurisdictions, and households may migrate if they consider the ratio of services received in relation to taxes paid superior elsewhere. The combined actions of households and firms may lead in turn to policy reactions at both the national and sub-national levels, triggering reforms to intergovernmental fiscal relations (OECD, 2014).

Fiscal decentralisation, which involves the devolution of government fiscal responsibilities to lower (sub-central) governments (SCG), has been discussed in many countries. A reason for this interest is the theoretical prediction that fiscal decentralisation enhances the efficiency of government and promotes economic development (Oates, 1993).

The aim of the article is to examine and quantify influence of fiscal decentralisation on output in the European Union in the period 1995-2012. The empirical evidence will be performed on a panel which contains 21 countries. Since fiscal decentralisation has many dimensions, the following indicators will be used in the empirical analysis: spending decentralisation, revenue decentralisation and tax revenue decentralisation. 


\section{Literature review}

Fiscal decentralisation is often discussed as a political issue in many countries, but the term is not sufficiently clear even in the fields of political science or public administration. Generally, fiscal decentralisation is linked to sharing of fiscal responsibilities and power among central, state and local governments. Akai and Sakala (2002) define fiscal decentralisation as devolution of the authority associated with decision making to a lower-level government. To measure fiscal decentralisation, it is necessary to know the degree of devolution or the level of authority of the lower-level government. Authority associated with decision-making has been allocated on the basis of legal relationships between higher and lower-levels government. However, it is difficult to measure the allocation of authority quantitatively. In Thiessen's (2003) point of view, fiscal decentralisation considers a transfer of responsibility associated with accountability to sub-national governments. He maintains that fiscal decentralisation is considered as the potential of sub-national governments to increase tax revenues, and make decision how to allocate their monetary resources to various projects within the legal boundary. Bird and Wallich (1993) note that fiscal decentralisation is observed as a portion of reform package for improving public sector efficiency, to raise competition among lower level government in supplying public goods and to accelerate economic growth.

Figure 1: Channels from decentralisation to economic activity

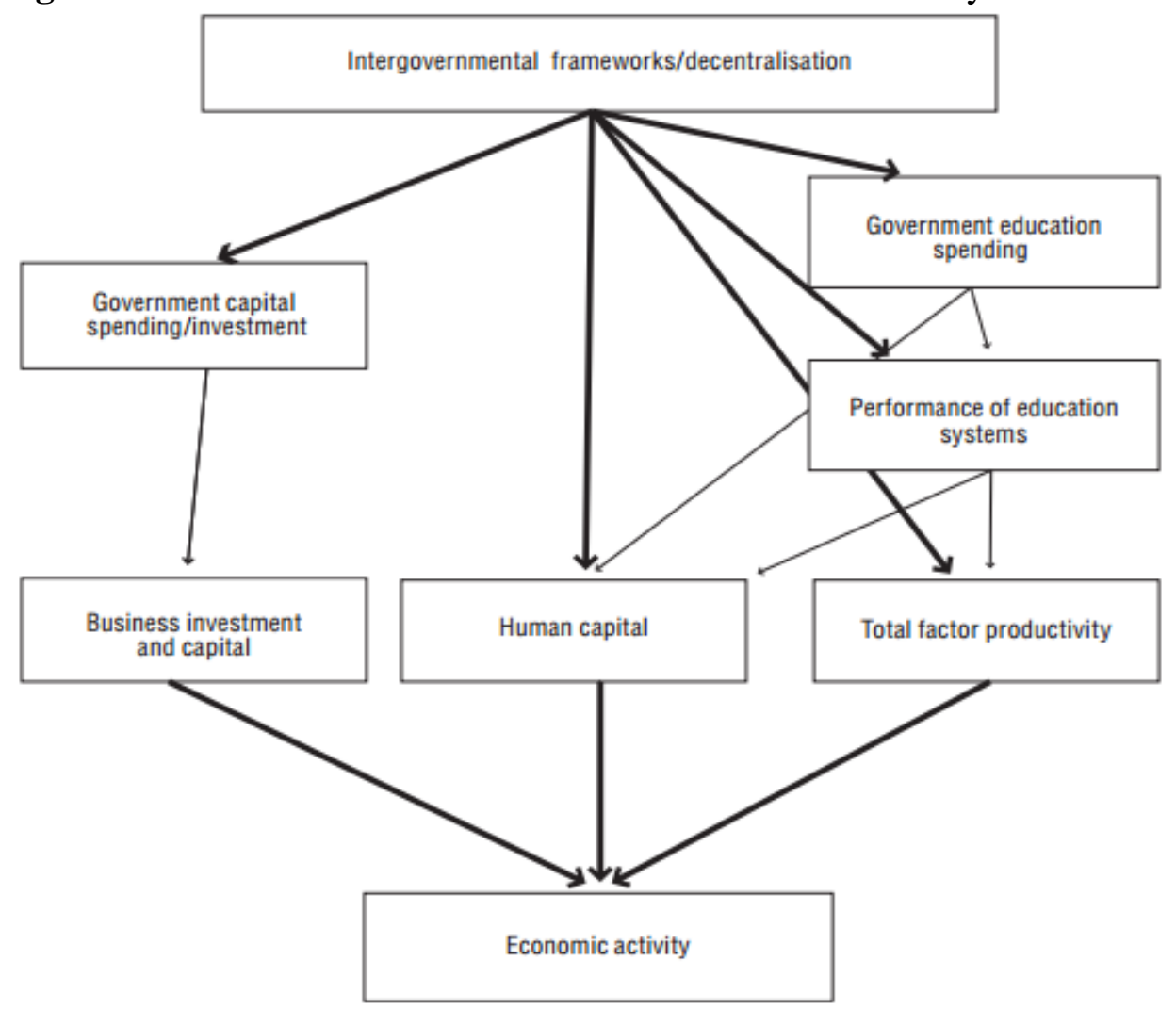

Source: OECD (2013)

As OECD (2013) points out, there are numerous channels through which fiscal decentralisation and an intergovernmental set-up affects an economy. Figure 1 illustrates some of the ways in which fiscal decentralisation can affect economic activity and development. In a macroeconomic production function, output is determined by physical and human capital and by their productivity, known as total factor productivity. Productivity in the private and public sector is, in turn, affected by institutional and policy settings like the extent of decentralisation. Since firms and households rely on public sector services, corporate 
productivity and household well-being may depend on how and where governments spend money. Fiscal frameworks might shape for example the extent to which governments - both national and sub-national - invest in infrastructure or education. Finally, fiscal decentralisation may directly affect a particular public sector (e.g. education system) whose performance can affect human capital formation.

Empirical studies focused on the relationship between fiscal decentralisation and economic growth provide mixed results. Rodríguez-Pose and Krøijer (2009) summarize arguments in favour of fiscal decentralisation. They claim it promotes higher efficiency, better public service, greater transparency and, eventually, economic growth. It is often argued that decentralisation increases economic efficiency because local governments are better positioned than the national government to deliver public services as a result of proximity and informational advantage. This proximity is particularly important in low-income countries or emerging markets where in absence of market opportunities, vulnerable populations rely heavily on state action for their survival.

Thornton (2007) highlights that the relationship between fiscal decentralisation and long-run economic growth is ambiguous as is apparent from the results of empirical studies. Several economists have made the case for fiscal decentralisation as means of promoting long-run economic growth based on the view that leads to better resource allocation and more productive, and possibly smaller, public sector. This might be because locally determined policies are better able to take account of regional and local conditions in the provision of public goods, such as infrastructure and education (Oates, 1993), or that competition among different levels of government promotes lower tax rates and the efficient production of public goods under revenue constraints (Brennan and Buchanan, 1980). Vazquez and McNab (2003) conclude that it provides incentives for local governments to innovate in the production and supply of public goods and services. Contrary, Tanzi (1995) argues that fiscal decentralisation can create for macroeconomic policy coordination generally, and for implementing stabilization policies in particular.

Blöchliger and Égert (2013) present a comprehensive overview of literature review, which is divided into two groups - cross-country studies and national studies. Most empirical studies are focused on the share of subnational government revenue or expenditure in consolidated (national and subnational) government revenue or expenditure as the measure of fiscal decentralisation. Studies that have reported a positive and statistically significant impact using these measures include, among others, Iimi (2005), who reports a significant and positive impact of expenditure decentralisation on per capita GDP growth in a panel of 51 developed and developing countries covering 1997-2001.

Akai and Sakata (2002) find that the ratios of local government revenue and expenditure to combined state and local government revenue and expenditure have a positive and statistically significant impact on state GDP in a panel study of US states covering 1992-1996. Also Thiessen (2003) describes a positive relation between decentralisation and growth when decentralisation is increasing from low levels, but that as decentralisation increased, the relation eventually turned negative in a cross section of high-income OECD economies using annual data for the period 1973-1998.

There is a group of studies that have found no statistically significant relation between growth and fiscal decentralisation. For instance, Thornton (2007) notes that recent studies examining the relation between fiscal decentralisation and economic growth have failed to take account 
of the extent of the independent taxing powers available to sub-national governments and thus have substantially overstated the degree of effective decentralisation. Results from his cross section study of 19 OECD member countries suggest that when the measure of fiscal decentralisation is limited to the revenues over which sub-national governments have full autonomy, its impact on economic growth is not statistically significant. Davoodi and Zou (1998) have similar conclusions and present negative but not statistically significant effect of expenditure decentralisation on economic growth for developing countries and no clear relationship for developed countries using panel data for 46 developed and developing countries covering the period 1970-1989.

Contrary to a majority view, it is possible to find many empirical studies with a proven negative impact of fiscal decentralisation on economic growth. Zhang and Zou (1998) demonstrate how the allocation of fiscal resources between the central and local governments has affected economic growth in China since reforms began in the late 1970s. They find that a higher degree of fiscal decentralisation of government spending is associated with lower provincial economic growth over the past fifteen years.

As well Rodríguez-Pose and Krøijer (2009) examine, using a panel data approach with dynamic effects, the relationship between the level of fiscal decentralisation and economic growth rates across 16 Central and Eastern European countries over the 1990-2004 period. Their findings suggest that there is a significant negative relationship between two out of three fiscal decentralisation indicators included in the analysis and economic growth. However, the use of different time lags allows them to nuance this negative view and show that long-term effects vary depending on the type of decentralisation undertaken in each of the countries considered. While expenditure and transfers to subnational tiers of government are negatively correlated with economic growth, tax as assigned at the subnational level evolve from having a significantly negative to a significantly positive correlation with the national growth rate. This supports the view that subnational governments with their own revenue source respond better to local demands and promote greater economic efficiency.

Next Rodríguez-Pose and Ezcurra (2011) analyse the relationship between decentralisation and economic growth in 21 OECD countries during the period between 1990 and 2005 controlling not only for fiscal decentralisation, but also for political and administrative decentralisation. The results point towards a negative and significant association between fiscal decentralisation and economic growth in the sample countries, a relationship that is robust to the inclusion of series of control variables and to differences in expenditure preferences by subnational governments. The impact of political and administrative decentralisation on economic growth is weaker and sensitive to the definition and measurement of political decentralisation.

Gemmell et al. (2013) investigate whether the efficiency gains accompanying fiscal decentralisation generate higher growth in more decentralized economies, applying pooledmean group techniques to a panel dataset of 23 OECD countries, 1972-2005. They find that spending decentralisation tends to be associated with lower economic growth while revenue decentralisation is associated with higher growth. Since OECD countries are substantially more spending than revenue decentralized, this is consistent with Oates' (1993) hypothesis that maximum efficiency gains require a close match between spending and revenue decentralisation. It suggests reducing expenditure decentralisation, and simultaneously increasing the fraction financed locally, would be growth-enhancing. 
Also Baskaran and Feld (2013) examine the effect of fiscal decentralisation on economic growth for twenty-three OECD countries from 1975 to 2008. In order to proxy fiscal decentralisation, they use both traditional Government Finance Statistics (GFS)-style measures and new measures that account for the degree of subnational tax autonomy. The regressions with GFS-style measures indicate that fiscal decentralisation has a negative but statistically insignificant effect on growth. Regressions with the new measures also result in negative coefficient estimates. However, they are larger in absolute terms and statistically significant.

Some authors, such as Rodden (2002), even consider decentralisation harmful, especially in the case of developing and transition economies This scepticism is fuelled by problems often associated with decentralisation, such as increasing deficits, lower quality of government decisions, corruption, increased influence of interest groups, and greater interregional inequalities, which may result in lower overall economic growth.

For the empirical literature on fiscal federalism, these results imply that measures of fiscal decentralisation that account for subnational tax autonomy should be preferred to traditional GFS-style measures. From a policy perspective, they conclude that policy makers should be aware of the economic trade-offs when pursuing reforms toward more fiscal decentralisation.

\section{Data and methodology}

The aim of the article is to examine and quantify influence of fiscal decentralisation on output in the European Union in the period 1995-2012 (the newest available data are from 2012). The results of the above empirical studies are rather heterogeneous, i. e. different articles report different relationship and impact of fiscal decentralisation on economic development. This may be due to differences in econometric models used, country samples, observation periods and considered variables.

The sample selection is limited by a membership of countries in OECD and the availability of data. The empirical evidence is performed for $21 \mathrm{EU}$ member states, namely Austria (AT), Belgium (BE), Czech Republic (CZ), Denmark (DK), Estonia (ES), Finland (FI), France (FR), Germany (GE), Greece (GR), Hungary (HU), Ireland (IR), Italy (IT), Luxembourg (LU), Netherlands (NL), Poland (PO), Portugal (PT), Slovak Republic (SK), Slovenia (SI), Spain (SP), Sweden (SWE) and United Kingdom (UK). The analysis uses data taken from OECD Fiscal Decentralisation Database and OECD.

Table 1: Descriptive statistics of variables

\begin{tabular}{|l|l|l|l|l|l|}
\hline & RGDP_ & GDP & EXPD_ & REVD_ & TAXD__ \\
\hline Mean & 5.32 & 22344.18 & 28.50 & 17.30 & 13.43 \\
\hline Median & 4.94 & 21400.00 & 28.91 & 14.87 & 9.05 \\
\hline Maximum & 20.00 & 68400.00 & 64.13 & 42.60 & 48.22 \\
\hline Minimum & -13.95 & 5300.00 & 4.05 & 2.43 & 0.76 \\
\hline Std. Dev. & 4.43 & 9800.25 & 12.79 & 9.45 & 12.35 \\
\hline Skewness & -0.24 & 1.74 & 0.38 & 0.72 & 1.04 \\
\hline Kurtosis & 4.69 & 8.78 & 3.18 & 2.51 & 2.97 \\
\hline Jarque-Bera & 48.14 & 717.12 & 9.39 & 35.66 & 68.45 \\
\hline Probability & 0.00 & 0.00 & 0.01 & 0.00 & 0.00 \\
\hline Sum & 1983.95 & 8446100. & 10774.69 & 6451.10 & 5076.22 \\
\hline Sum Sq. Dev. & 7301.83 & $3.62 \mathrm{E}+10$ & 61625.33 & 33211.53 & 57485.36 \\
\hline Observations & 373 & 378 & 378 & 378 & 378 \\
\hline
\end{tabular}

Source: based on data from OECD 
Economic development is assessed using the GDP growth rate (RGDP) and nominal GDP per capita (GDP) expressed in Purchasing Power Standard per inhabitant. Table 1 presents basic descriptive statistics of variables. Since fiscal decentralisation has many dimensions, following indicators are used in the empirical analysis: expenditure decentralisation, revenue decentralisation and tax revenue decentralisation. The variables are specified in line with OECD methodology as follows:

- Expenditure decentralisation (EXPD) is the ratio of sub-central to total general government spending;

- Revenue decentralisation (REVD) means the ratio of sub-central own revenue to total general government revenue;

- Tax revenue decentralisation (TAXD) expresses the ratio of sub-central tax revenue to total general government tax revenue.

It is needful to test the stationary time series before starting the analysis (GDP time series are first converted into logs). Unit root tests identified that all time series are stationary at the first differences (RGDP and EXPD also at level data). Explanatory variables are chosen in accordance to Blöchliger (2013). They are not examined in individual regresions, but the analysis newly uses Generalized Method of Moments (Dynamic Panel Data). The basic models are defined in (2) and (3) and variables are explained above:

$$
\begin{aligned}
& d R G D P_{i t}=\alpha_{i}^{*}+\beta 1 * d E X P D_{i t}+\beta 2 * d R E V D_{i t}+\beta 3 * d T A X D_{i t}+\beta 4 * d F R I_{i t}+u_{i t} \\
& d G D P_{i t}=\alpha_{i}^{*}+\beta 1 * d E X P D_{i t}+\beta 2 * d R E V D_{i t}+\beta 3 * d T A X D_{i t}+\beta 4 * d F R I_{i t}+u_{i t}
\end{aligned}
$$

The constants are specific to the $i$-th unit (country) at time $t$, at the same time but are constant. $\beta$ ' is the vector dimension $1 x K$ constants and $\alpha_{i}^{*}$ is a constant representing the effects of those variables which are characteristic of the $i$-th observation. $u_{i t}$ error component represents nonsignificant effects of variables inherent in the $i$-team observations and a given time interval.

The generalized method of moments (GMM) is a generic method for estimating parameters in statistical models. It is usually applied in the context of semiparametric models, where the parameter of interest is finite-dimensional, whereas the full shape of the distribution function of the data may not be known. GMM is common in estimating structural economic models,as it requires much less conditions on model disturbances than Maximum Likelihood. Another important advantage includes the fact that it is easy to obtain parameter estimates that are robust to heteroskedasticity of unknown form (Hansen, 1982). For a model specification, Dynamic Panel Data Model Wizard is applied. This wizard aids in specifying a member of the class of dynamic panel data models with fixed effects. These models are designed for panels with a large number of cross-sections and a shorter time series (Arellano and Bond, 1991).

\section{Results and discussion}

The sample of the examined countries covers 1 regional (Spain is constitutionally a nonfederal country with a highly decentralised political structure) and 3 federal countries (Austria, Belgium, Germany) with central, state and local governments, other 17 countries are unitary with central and local governments. As Figure 2 shows, there are significant diffrences among scope of fiscal decentralisation in coutries and variables.

The expenditure decentralisation indicator (EXPD) is defined for each state as the ratio of local and state government expenditure to global total general expenditure at general government level plus the total inter-governmental property expenditure. The addition is made because the latter represents payments by one level of government for a service 
provided by another government level and it essentially avoids consolidation of property expenditure at general government level. This indicator corresponds to the most approximate measure of the allocation of authority when a subnational government has authority associated with its expenditure implicitly considering that all inter-governmental grants are non-matching or lump-sum grants. The revenue decentralisation indicator is defined for each state as the ratio of own local and state government revenue (total revenue minus the intergovernmental transfer revenue of that government level) to total general government revenue. Finally, tax revenue decentralisation is the ratio expressing share of sub-central tax revenue to total general government tax revenue. Consolidated total general government revenue is defined as global total revenue at general government level plus the total intergovernmental property income. The addition is made because the latter represents payments by one level of government for a service provided by another government level and it essentially avoids consolidation of property income at general government level. These revenue indicators corresponds to the most common argument of the allocation of authority when the government that collects revenue has authority associated with its own revenue or the tax to be collected (Oates, 1993).

Figure 2: Fiscal decentralisation in 2012 (in \%)

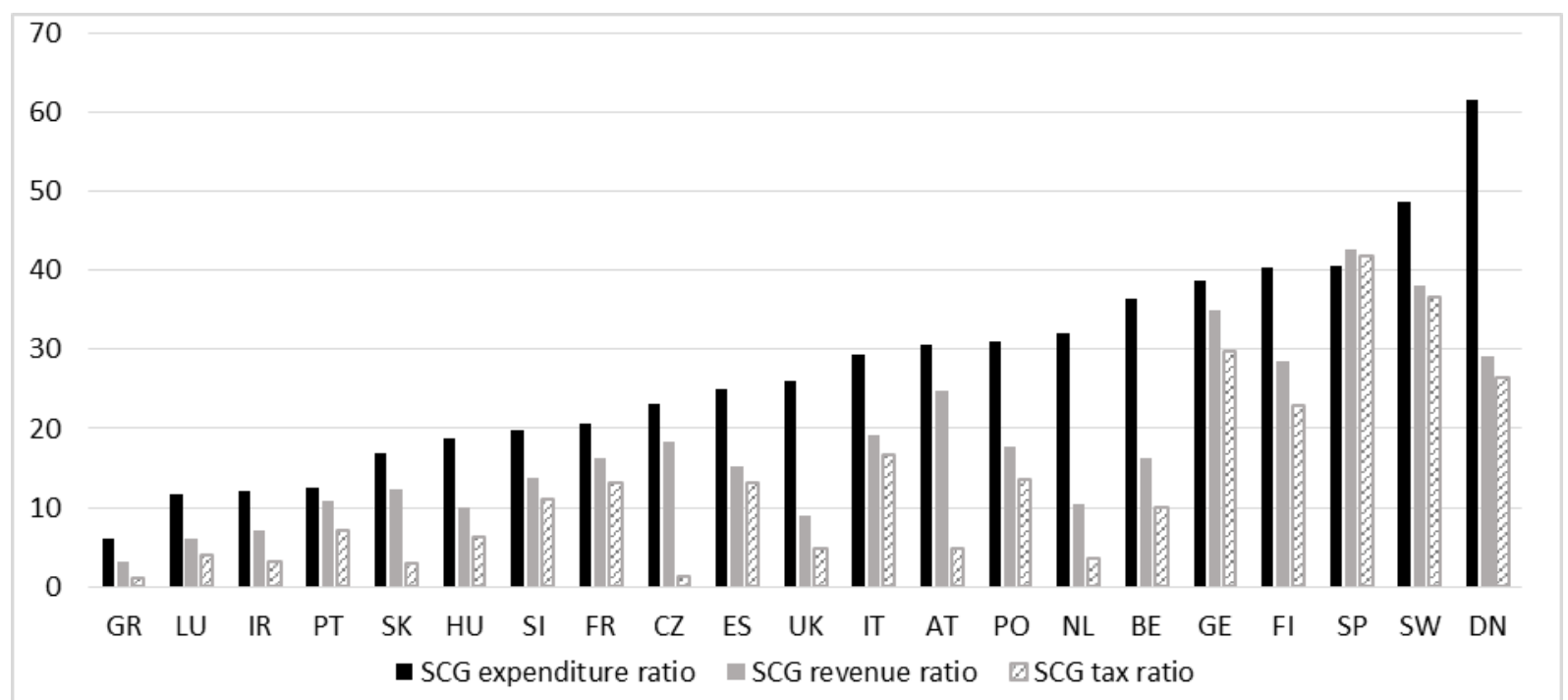

Source: author's compilation based on data from OECD

Sub-central expenditure (spending) share averaged around $28 \%$ in 2012, with values ranging between $61 \%$ for Denmark and $12 \%$ for Ireland, while the revenue decentralisation share is at around $18 \%$, with values between $38 \%$ for Sweeden and $3 \%$ for the Greece. Tax revenue decentralisation varies from $1 \%$ in Greece and the Czech Republic to $47 \%$ in Austria, with average value $14 \%$. Spendings are clearly more decentralized than revenues, with a considerable part of sub-central expenditure covered by intergovernmental grants. Constitutional provisions explain only a part of the differences in sub-central autonomy as various federal countries appear more centralized than some unitary ones. While both revenue and expenditure became more decentralized over the past 20 years, expenditure decentralisation outpaced revenue decentralisation, resulting in a higher vertical fiscal imbalance and growing intergovernmental grants (for details look at Halásková and Halásková, 2014 or OECD, 2013). Only a few countries - in particular Spain and Italy (details are below) that embarked on a secular decentralisation process and a few Eastern European economies such as Estonia and Poland - underwent considerable changes in subcentral spending and taxation powers. Ireland singnificantly decreased expenditure 
competences of sub-central government in relation to the consolidation of public budgets and spendings to rescue the banking sector.

Tax autonomy is extremely low and the freedom of sub-central governments to introduce or to abolish a tax, to set tax rates, to define the tax base, or to grant tax allowances or reliefs to individuals and firms is considerably limited in countries as the Czech Republic, Ireland or Greece (Szarowská, 2013 and 2014). Decentralisation appears to converge towards an intermediate level, with a few highly decentralized countries recentralizing and several highly centralized countries devolving fiscal powers to lower government levels.

The degree of decentralisation varies widely across the sample countries but has changed little over the analyzed period, with a few notable exceptions. Figure 3 depicts changes of fiscal decentralisation ratios. Values of all analyzed decentralisation ratios increased in average between 1995-2012, the highest average increase is noticed by tax decentralisation ratio (3.14 percentage points), the revenue decentralisation ratio increased in average by 2.40 percentage points and a share of sub-central to total general government expenditure increased in average by 1.5 percentage points.

Figure 3: Changes of fiscal decentralisation ratios between 1995-2012 (in percentage points)

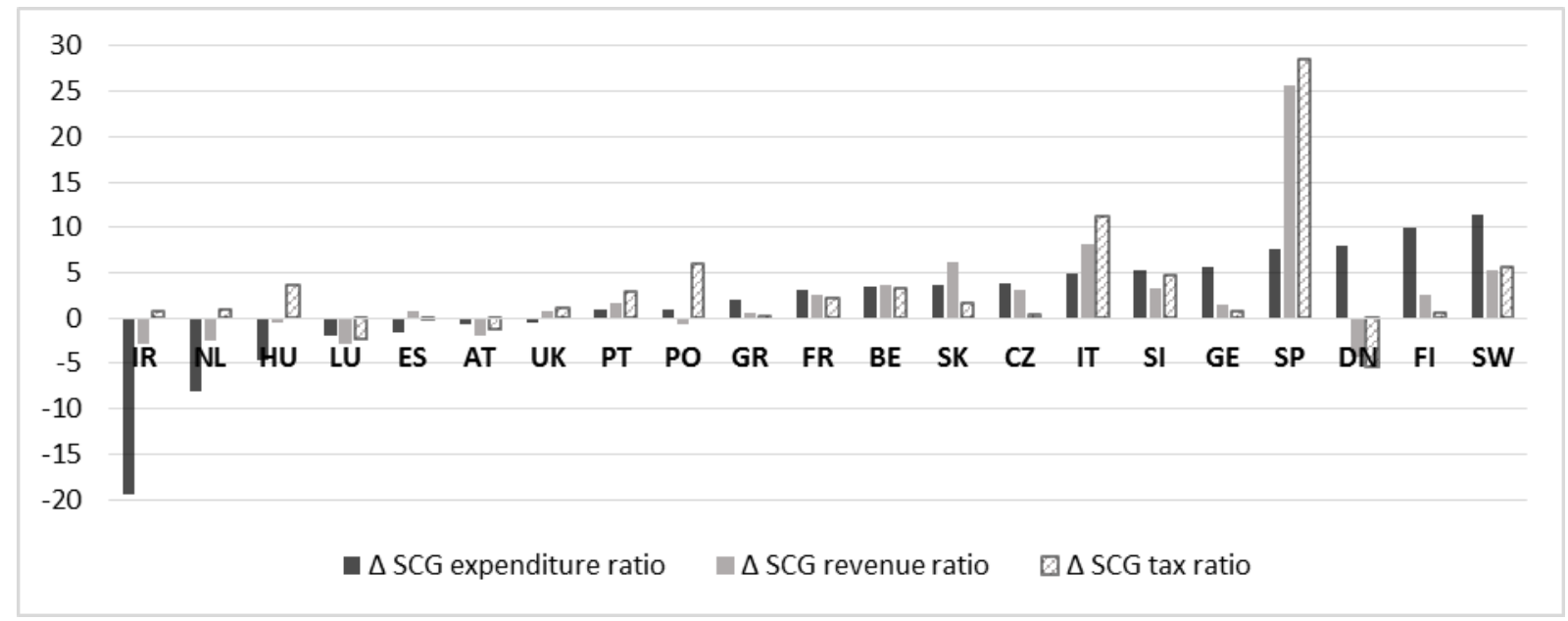

Source: author's compilation based on data from OECD

Generally, reforms to intergovernmental fiscal frameworks can explain a part of the evolution of decentralisation indicators over the past 20 years. The most common fiscal federalism reforms include: the devolution of new responsibilities for public services to the sub-central level, especially in the area of economic affairs and social welfare; the upgrading and amendment of equalisation and other intergovernmental grant systems, particularly a move from earmarked to non-earmarked grants; the introduction or tightening of sub-central fiscal rules; a move from grants to tax sharing; and sub-central tax reforms, mostly entailing a stronger harmonization of central and sub-central tax bases (Blöchliger, 2013).

As mentioned above, Italy and Spain have started decentralisation reform process. In 2009, the Italian parliament endorsed Law 42 on fiscal federalism, setting a milestone for Italy's gradual move towards decentralisation and federal institutions. The law, which is based on a constitutional amendment passed in 2001, increased tax and spending autonomy of the regions, provinces and municipalities and overhauled the equalisation system, tackling the wide fiscal interregional differences. A set of legislative decrees, some of which have not been implemented yet, determines intergovernmental tax arrangements, equalisation, fiscal 
rules and accounting harmonization. As Blöchliger and Vammalle (2012) report, Spain has undergone a deep process of political and fiscal decentralisation, shifting from a highly centralised system to a highly decentralised one in the last three decades. The Spanish system of financing Autonomous Communities (AC), which was created in the 1980s, provided for a renegotiation every five years. Each round of negotiation raised political tensions and subjected the central government to additional costs for reaching an agreement. The AC finance law (LOFCA: Ley Orgánica de Financiación de las Comunidades Autónomas) adopted in 2001 was supposed to remain in force indefinitely and thus to avoid such problems. However, since it did not include mechanisms to adapt to asymmetric shocks, it was criticised for generating inefficiencies and inequities in revenue allocation, so the need to reform the system became apparent. In December 2009, a new LOFCA was passed by the national parliament and subsequently ratified by all the ACs. This reform focused on the revenue side of the ACs. It does not touch the roles and responsibilities of each level of government, which had already been widely decentralized.

The empirical studies above mostly conclude that decentralisation appears to be positively associated with GDP per capita levels but negatively associated with real GDP growth (e.g. see Szarowská, 2014). In any case, findings should be interpreted with caution as economic growth does not depend exclusively on the degree of fiscal decentralisation of a country (coefficients of determination are very low). The same conclusion is possible to find in Davoodi and Zou (1998), Akai and Sakata (2002), limi (2005) or Thornton (2007). The potential influence of the degree of fiscal decentralisation on economic performance may be affected by country differences in political and administrative decentralisation (RodríguezPose and Ezcurra, 2011).

In order to test whether fiscal decentralisation matters for economic performance, econometric models expressed in a basic form for GDP growth in (2) and for GDP per capita in (3) are estimated. Table 2 presents the most appropriate specifications of models resulting from GMM (results of other estimations are available on request).

Table 2: Dynamic panel data estimations

\begin{tabular}{|c|c|c|c|c|c|c|}
\hline \multirow[t]{2}{*}{ Dependent variable } & \multicolumn{3}{|c|}{$\Delta \mathbf{G D P}_{-}$} & \multicolumn{3}{|c|}{$\Delta \mathbf{R G D P}_{-}$} \\
\hline & Coefficient & Std. Error & t-Statistic & Coefficient & Std. Error & t-Statistic \\
\hline$\Delta \mathrm{GDP}_{(-1)}$ & $0.284^{*}$ & 0.016 & 17.864 & & & \\
\hline$\Delta \mathrm{GDP}_{(-2)}$ & $-0.074 *$ & 0.028 & -2.676 & & & \\
\hline$\Delta \operatorname{RGDP}_{(-1)}$ & & & & $-0.156^{*}$ & 0.050 & -3.126 \\
\hline$\Delta \mathrm{RGDP}_{(-2)}$ & & & & $-0.387 *$ & 0.029 & -13.213 \\
\hline$\Delta \mathrm{EXPD}$ & $0.003 *$ & 0.001 & 4.622 & $0.205^{*}$ & 0.102 & 2.013 \\
\hline$\triangle \mathrm{REVD}$ & $-0.008 *$ & 0.002 & -3.410 & $-1.900 *$ & 0.305 & -6.226 \\
\hline$\Delta \mathrm{TAXD}$ & -0.004 & 0.003 & -1.292 & -0.251 & 0.357 & -0.702 \\
\hline Total observations & \multicolumn{3}{|c|}{315} & \multicolumn{3}{|c|}{315} \\
\hline Mean & \multicolumn{3}{|c|}{0.016} & \multicolumn{3}{|c|}{0.309} \\
\hline S.D. dependent var. & \multicolumn{3}{|c|}{0.040} & \multicolumn{3}{|c|}{3.821} \\
\hline S.E. of regression & \multicolumn{3}{|c|}{0.043} & \multicolumn{3}{|c|}{4.258} \\
\hline J-statistic & \multicolumn{3}{|c|}{19.436} & \multicolumn{3}{|c|}{18.003} \\
\hline Instrument rank & \multicolumn{3}{|c|}{21} & \multicolumn{3}{|c|}{21} \\
\hline
\end{tabular}

Note: symbol * denotes statistical significance at the $1 \%$ level

Source: author's calculation based on data from OECD 
Focusing on the effect of decentralisation, it is found that even after using dynamic panel data analysis, the main result concerning the effect of fiscal decentralisation survives; that is, the main results obtained from the panel regression are similar to those obtained in earlier empirical studies. Table 2 shows that the estimated coefficients on expenditure fiscal decentralisation are positive and statistically significant at the $1 \%$ level. This finding confirms that increase of state and local expenditure contributes to the economic growth and GDP per capita, too.

Revenue decentralisation seems to have negative impact on economic development as coefficients are negative and statistically significant during the period of the analysis. Tax revenue decentralisation has a negative but not significant impact on economic growth and economic level of the countries in the years of the analysis. This findings are particularly interesting as the relationship between the different decentralisation measures and economic performance evolves in opposite directions and countries tend to increase revenue fiscal decentralisation over the last years. The obtained results suggest that impact of fiscal decentralisation is higher and more intensive on economic level increase than on GDP growth.

In terms of subnational expenditure and revenues, the results are in line with the findings of other empirical studies on fiscal decentralisation and economic growth, such as Akai and Sakata (2002), Thiessen (2003), Iimi (2005) or Rodríguez-Pose and Krøijer (2009), but opposite to Zhang and Zou (1998), Rodden (2002) or Rodríguez-Pose and Ezcurra (2011). The variety is generated due to differences in used econometric models, country samples, observation periods and considered variables.

\section{Conclusion}

This article investigates the impact of fiscal decentralisation on a long-term economic development. The aim of the article was to test and quantify influence of fiscal decentralisation on output in the European Union in the period 1995-2012. The empirical evidence is performed on a panel which contains 21 countries. The analysis used data taken from OECD Fiscal Decentralisation Database and OECD. Since fiscal decentralisation has many dimensions, the following indicators were used in the empirical analysis: expenditure decentralisation, revenue decentralisation and tax revenue decentralisation. The empirical tests relating decentralisation and economic performance were based on dynamic panel data model, the estimation used Generalized Method of Moments.

The results suggest that the degree of decentralisation varies widely across sample countries but has changed only fractionally over the analyzed period. Sub-central expenditure share averaged around 28\%, with values ranging between $61 \%$ for Denmark and $12 \%$ for Ireland, while the revenue decentralisation shares at around 17\%, with values between $38 \%$ for Sweeden and 3\% for Greece in 2012. Tax revenue decentralisation varies from 1\% in Greece and the Czech Republic to $47 \%$ in Austria, with average value 13\%. Expenditure side is more decentralized than revenues, with a considerable part of sub-central expenditure covered by intergovernmental grants.

The findings of dynamic panel analysis comfirm positive and significant impact of expenditure decentralisation effect on economic growth and GDP per capita growth. They also identified negative and significant effect of revenue decentralisation on economic performance and negative but statistically insignificant impact of tax decentralisation. 
These findings are enormously interesting as the relationship between the different decentralisation measures and economic performance evolves in opposite directions and countries have tended to increase revenue fiscal decentralisation over the last years.

Based on the empirical results, the study suggests that state and local governments should be given more autonomy and authority in fiscal expenditure matters. Generally, decentralisation is often associated with increased degrees of policy innovation, greater transparency, and better capacity of governments to adapt policies to local needs. On the other hand, the evidence did not confirm revenue decentralisation expectation about the ability of local governments to generate their own revenues and promoting fiscal responsibility and incentivize them.

\section{Acknowledgement}

This article was supported by the Ministry of Education, Youth and Sports of the Czech Republic within the Institutional Support for Long-term Development of a Research Organization in 2015.

\section{References}

[1] AKAI, N. and M. SAKATA, 2002. Fiscal decentralisation contributes to economic growth: evidence from state-level cross-section data for the United States. Journal of Urban Economic, 52(1), 93-108. ISSN 0094-1190.

[2] ARELlANO, M. and S. BOND, 1991. Some tests of specification for panel data. The Review of Economic Studies, 58(2), 277-297. ISSN 1467-937X.

[3] BASKARAN, T. and L. P. FELD, 2013. Fiscal Decentralisation and Economic Growth in OECD Countries. Is There a Relationship? Public Finance Review, 41(4), 421-445. ISSN 1091-1421.

[4] BIRD, R. M. and C. I. WALLICH, 1993. Fiscal Deentralisation and Intergovernmental Relations in Transition Economies [online]. March 1993 [vid. 10.012015]. Available from: http://www-wds.worldbank.org/servlet/WDSContentServer/WDSP/IB/1993/03 /01/000009265_3961004094828/Rendered/PDF/multi0page.pdf

[5] BLÖCHLIGER, H., 2013. Decentralisation and Economic Growth-Part 1: How Fiscal Federalism Affects Long-Term Development. OECD Working Papers on Fiscal Federalism, 2013(14), 1-23. ISSN 2226-5848.

[6] BLÖCHLIGER, H. and B. ÉGERT, 2013. Decentralisation and economic growth - Part 2: The impact on economic activity, productivity and investment. OECD Working Papers on Fiscal Federalism, 2013(15), 1-25. ISSN 2226-5848.

[7] BLÖCHLIGER, H. and C. VAMMALLE, 2012. Reforming Fiscal Federalism and Local Government: Beyond the Zero-Sum Game. Luxembourg: OECD Publishing. ISBN 97892-64-09841-1.

[8] BRENNAN, G. and J. BUCHANAN, 1980. The Power to Tax: Analytical Foundations of a Fiscal Constitution. Cambridge: Cambridge University Press. ISBN 9780521027922 .

[9] DAVOODI, H. and H. ZOU, 1998. Fiscal decentralisation and economic growth: A cross-country study. Journal of Urban Economics, 43(2), 244-257. ISSN 0094-1190.

[10] GEMMELL, N., R. KNELLER and I. SANZ, 2013. Fiscal Decentralisation and Economic Growth. Economic Inquiry, 51(4), 1915-1931. ISSN 1465-7295. 
[11] HALÁSKOVÁ, M. and R. HALÁSKOVÁ, 2014. Impacts of decentralisation on the local government expenditures and public services in the EU countries. Lex LocalisJournal of Local Self-Government, 12(3), 623-642. ISSN 1581-5374.

[12] HANSEN, L. P., 1982. Large Sample Properties of Generalized Method of Moments Estimators. Econometrica, 50(4), 1029-1054. ISSN 1468-0262.

[13]IIMI, A., 2005. Decentralisation and economic growth revisited: An empirical note. Journal of Urban Economics, 57(3), 449-461. ISSN 0094-1190.

[14] OATES, W. E., 1993. Fiscal decentralisation and economic development. National Tax Journal, 46(2), 237-243. ISSN 0028-0283.

[15] OECD, 2013. Fiscal federalism 2014: Making decentralisation work. Paris: OECD Publishing. ISBN 9789264204560.

[16]RODDEN, J., 2002. The dilemma of fiscal federalism:grants and fiscal performances around the world. American Journal of Political Science, 46(3), 670-687. ISSN 15405907.

[17]RODRÍGUEZ-POSE, A. and R. EZCURRA, 2011. Is fiscal decentralisation harmful for economic growth? Evidence from the OECD countries. Journal of Economic Geography, 11(4), 619-643. ISSN 1468-2710.

[18] RODRÍGUEZ-POSE, A. and A. KRØIJER, 2009. Fiscal Decentralisation and Economic Growth in Central and Eastern Europe. Growth and Change, 40(3), 387-417. ISSN 00174815 .

[19] SZAROWSKÁ, I., 2014. Fiscal decentralisation and economic development in selected unitary European countries. European Financial and Accounting Journal, 9(1), 22-40. ISSN 1802-2197.

[20] SZAROWSKÁ, I., 2013. Effects of taxation by economic functions on economic growth in the European Union. In: E. JIRCIKOVA, A. KNAPKOVA and E. PASTUSZKOVA, eds. Proceedings of the 6th International Scientific Conference: Finance and the performance of Firms in Science, Education and Practice. Zlin: Tomas Bata University, pp. 746-758. ISBN 978-80-7454-246-6.

[21]TANZI, V., 1995. Fiscal federalism and decentralisation: A review of some efficiency and macroeconomic aspects. In: M. BRUNO and B. PLESKOVIC, eds. Annual World Bank Conference on Development Economics. Washington, DC: World Bank, pp. 295316. ISBN 0-8213-2908-1.

[22] THIESSEN, U., 2003. Fiscal decentralisation and economic growth in high income OECD countries. Fiscal studies, 24(3), 237-274. ISSN 1475-5890.

[23] THORNTON, J., 2007. Fiscal Decentralisation and Economic Growth Reconsidered. Journal of Urban Economics, 61(1), 64-70. ISSN 0094-1190.

[24] VASQUEZ, J. and R. M. Mc NAB, 2003. Fiscal decentralisation and economic growth. World Development, 31(9), 1597-1616. ISSN 0305-750X.

[25]ZHANG, T. and H. ZOU, 1998. Fiscal decentralisation, public spending, and economic growth in China. Journal of Public Economics, 67(2), 221-240. ISSN 0047-2727. 